\title{
超高鉄筋コンクリート煙突の設 計と施工
}

\section{DESIGN AND CONSTRUCTION OF A TALL REINFORCED CONCRETE STACK}

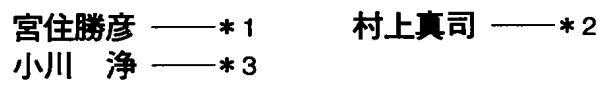

キーワード :

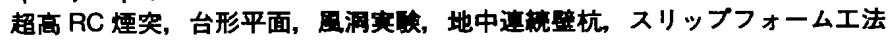

Keywords :

Tall RC stack, Trapezoidal plan, Wind tunnel test, Wall foundation pile, Slip form construction method

\section{Katsuhiko MIYAZUMI -*1 Kiyoshi OGAWA — $* 3$ \\ Masashi MURAKAMI — $* 2$}

A tall reinforced concrete stack in height of $200 \mathrm{~m}$, is reported on the structural design scheme and construction method. The stack has a trapezoidal plan with cut backs at four corners. Structural performance under strong winds was monitored in the wind tunnel tests. New construction system is adopted including development of bond preventive slip form. Wall foundation concrete pile contributes to producing a stable continuous structure system.
1.はじめに

近年，超高煙突の設計に際しては，煌突本来の機能面だけではな く景観にも配慮した形状が要求されるようになってきている。

德島県阿南市の䨩湾内に建設されている四国電力儌湾発電所 (石炭専焼火力 70 万 KW 1 基）においては高さ $200 \mathrm{~m}$ の煙突に鉄筋 コンクリート造の台形断面を採用し, 発電所のシンボルとなるよう 配虑している。

本煙突は風荷重が支配的となるため, 耐風設計に際しては風洞実 験により台形の隅角部の形状の違いが渦励振力の特性に与える効果 を調查し, 設計用風荷重を合理的に評価した。基礎形式は, 従来, 地震や風による転倒モーメントに抵抗するため, 極厚な基礎マット を設け，杭を配置する計画が多く用いられてきた。今回は筒体部か ら基礎部への応力伝達を容易にするため筒体部直下に地中連続壁杭 を配置し，杭先端を岩盤中に梁く貫入させることにより，筒体部と 基碟部の連続性を高めた。また筒体工事では複雑な形状変化に対応 できるように，様々な改良を施した高性能スリップフォームシステ ム（SF）を用い，型枠には付着防止性能を有する特殊パネルを採用 した。

\section{2. 煙突概要}

表 1 には烰突概要を示す。

写真 1 には, 工事完了後の煙突の写真を示す。

図 1 には，煙突形状の立面図，平面図及じ杭伏図を示す。

\section{表 1 煙突概要}

\begin{tabular}{|c|c|}
\hline 体 & 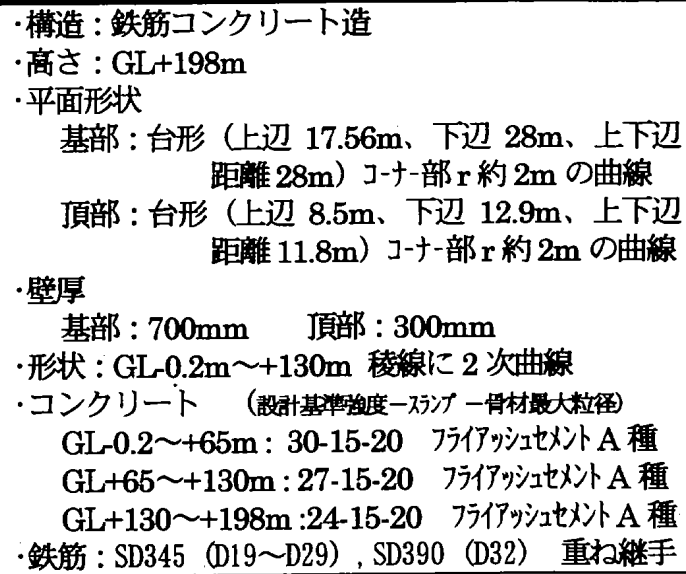 \\
\hline 内 䉍 & $\begin{array}{l}\cdot \text { 構造 : FRP 笠 } \\
\text { ·高さ }: \mathrm{GL}+200 \mathrm{~m} 1 \text { 筒 } \\
\text { ·平面形状 : 円简形 内径 } 6.6 \mathrm{~m} \\
\end{array}$ \\
\hline 基 碳 部 & 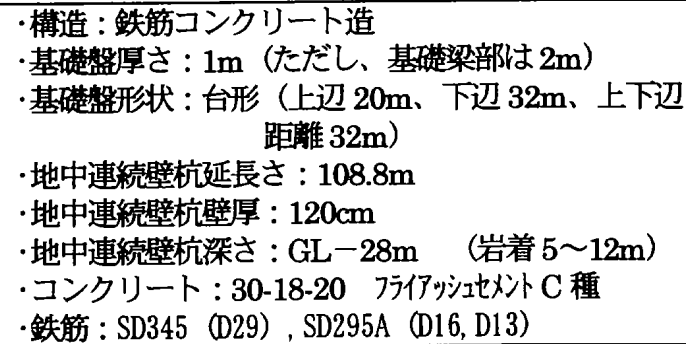 \\
\hline
\end{tabular}

\footnotetext{
*1 四国電力侏欈湾火力建設所建築第二課 課長 ( $7779-1631$ 德島県阿南市㢦町小勝 1 番地)

*2 四国電力侏橘湾火力建設所建筑第二課 副長

*3 四国電力侏㢦漟火力建設所建筑第二課
}

*1 Manager, Shikoku Electric Power Corporation, Tachibana Electric Power Plant

*2 Assistant Manager, Shikoku Electric Power Corporation, Tachibana Electric Power Plant

*3 Shikoku Electric Power Corporation, Tachibana Electric Power Plant 


\section{3. 煙突の權造設計概要}

\section{1 耐風設䂥}

本煙突の概略設計において，煌突の規模と動特性から設計風速の 範囲に渦励振の発生が予測された。渦励振の特性は煙突の隅角部の 形状が大きく影響するため，基準平面の形状を決定するため隅角部 の形状を変化させて風洞実験を行った。基本平面台形の隅角部の形 状は, Type-1（隅切り部の台形辺長に対する割合 0/18), -2（同 1/ 18)，-3 (同 $2 / 18$ 角型)，-4 (同 $2 / 18$ 丸型)， -5 (同 3/18）の 5 タイ プとした。

風洞実験は，林組技術研究所の多目的大型風河で実施した。 風洞気流は，建設予定地の状況から建築物荷重指針 (日本建築学会) の地表粗度区分 II と想定した。煙突の模型は風洞気流の縮尺にあわ せて $1 / 400$ とした。設計用風荷重は, 建築センター指針と建築学会指 針に基づいて，頂部風速をレべル1（再現期間 100 年）では $62.4 \mathrm{~m} / \mathrm{sec} ，$ レベル 2 (再現期間 500 年) では $72.4 \mathrm{~m} / \mathrm{sec}$ として設定し た。

模型に作用する空気力は，天科装置を用いて煙突構造軸 $(\mathrm{X}, \mathrm{Y})$ にあわせて测定した。1 風向当たりのデーターの収録はサンプリン グ周波数を $200 \mathrm{~Hz}$ ，計測時間を 60 秒間とした。計測した空気力は(1) 式の転倒モーメント係数として定義し, 実時間 10 分間相当 4 組のア ンサンブル平均から平均空気力係数, 変動空気力係数を評価した。

$$
C_{M}=\frac{M}{1 / 2 \rho U_{H}^{2} D H^{2}}
$$

ここで, $M$ : 転倒モーメントの時系列データ, $U_{H}$ : 煙突頂部高さ の平均風速， $D$ : 煙突模型の代表長さ (基部), $H$ : 煙突の頂部高さ である。空気力係数の結果は風向方向及び風直角方向について図 2 に示す。風直交方向の平均転倒モーメント係数に関する限り，隅角 部の形状の影響はわずかであるが，風方向の平圴転倒モーメント係 数と変動転倒モーメント係数は, 隅切りが大きくなると係数が小さ くなる傾向にある。変動転倒モーメント係数は風直交方向では風向 角 0 度で最大值を示し，風向角 90 度，180 度付近で極值を示す傾向 があった。ただし，風向角 0 度で風值角方向の変動転倒モーメント係 数のスペクトル密度は, 風の乱れよりも高い周波数の広域帯でピー クを示し，渦力と思われる狭城帯のピークは認められなかった。

風向角 90 度・X 方向振動と 180 度・Y 方向振動におけるパワース ペクトル密度を図 3 に示す。いずれの夕イプでも明確な渦力のピー クが現れているが,タイプによってピーク值と周波数に違いがある。 隅角部の隅切りの程度が大きくなるとスペクトル值は小さくなる傾 向にあるが，風向方向 180 度の $\mathrm{Y}$ 方向の渦力は Type-3 の場合にス ペクトル值が大きくな傾向がある。空力不安定性の指標である Den Hartogの判定式”を適用すると図4 となる。風向き角が 80 ～100 度，160〜180 度において値は負となるので空力不安定振動の 発生が予測されたが, Type-4の煙突について空力振動実験 (風向き 角 180 度)を行った結果, 設計風速範囲では渦励起振動はあるが, 発 散的な現象は発生しなかった（図 5)。

タイプ毎の設計用風荷重を比較するために，モーダルスペクトル 法を適用して煙突の 1 次固有周期を変化させて, レベル 2 の設計風 速範囲内における最大変形に相当する転倒モーメントを算定した。 初期減衰を $2 \%$ とて算定した結果を図 6 に示す。周期が短いと形 状による違いが明瞭に現れるが，周期が長いと設計用風荷重はほと

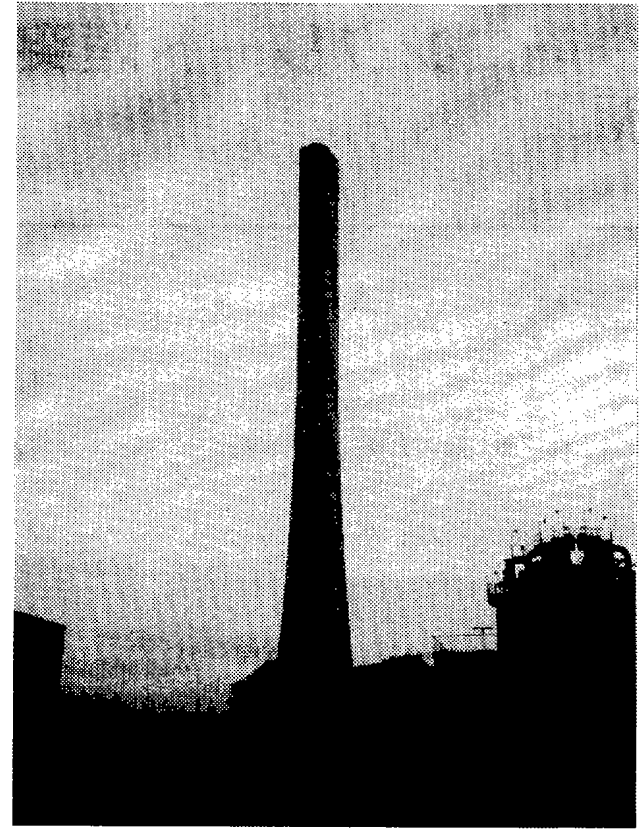

写真 1 煙突全景

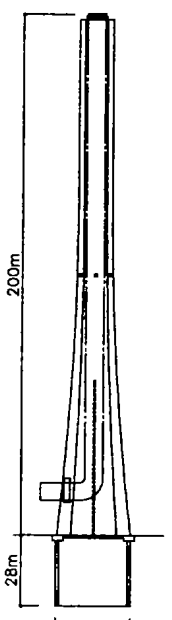

(a) 立面図

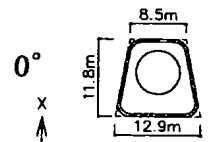

(b) 頂部 $(G L+198 m)$ 平面図

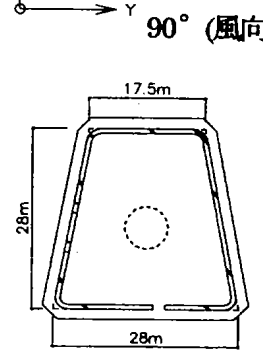

(c) 基部平面図

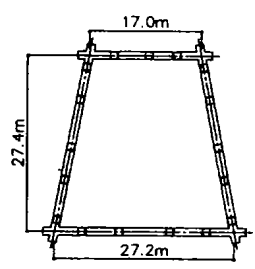

(d) 杭伏図
図 1 煙突概要
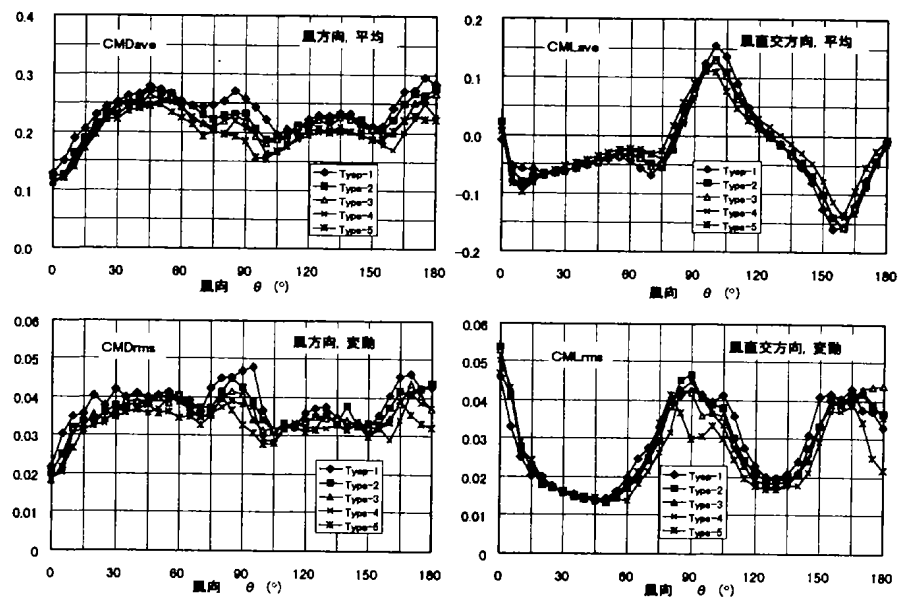

図 2 転倒モーメント係数 
んど一定である。そこで, 目標周期を X 方向を 2.2 秒, $\mathrm{Y}$ 方向を 2.4 秒と想定して，煙突の基本平面形状を Type-4 とした。

\section{2 和足設尌}

耐震設計における設計用地震力は, 地震応答解析によって算定す る。解析モデルは, 20 質点系曲げせん断型モデルとし 1 階固定とし た。 1 次固有周期は, $\mathrm{X}$ 方向 2.20 秒, $\mathrm{Y}$ 方向 2.37 秒である。入力地 震波は，最大速度により基準化しレベル 1 で $20 \mathrm{~cm} / \mathrm{sec，レベル} 2$ で $40 \mathrm{~cm} / \mathrm{sec}$ とした EL CENTRO(NS), TAFT(EW), HACHINOHE (NS), OSAKA205（EW）を用いた。弾塑性復元力特性は, 曲げに ついて考虑する。せん断に対する設計目標は, 最大せん断応力度が 第 1 折れ点以下であるので解析上, 弾性とした。曲げモーメントと曲 率の関係は, $M c=(1.8 \sqrt{F c}+\sigma v) Z e ；(F c ：$ コンリート強度, $\sigma v$ ： 長期軸応力度, $\mathrm{Ze}$ ：コンクリート断面係数)により算定したコンク リートのひび割れ点 $(\boldsymbol{M c}, \boldsymbol{\Phi} \boldsymbol{c})$, 引張最外縁鉄筋の降伏点 $(\boldsymbol{M} y$, $\Phi y)$ ，及び圧縮㑡 コンクリートが終局歪 $(0.4 \%)$ となる終局点 $(M u$, $\Phi u) の 3$ 点で定まるトリリニアー型とした。モーメントと曲率の関 係を定める際には, 断面の平面保持を仮定し, コンクリートの応力 〜歪み関係に $e$ 関数を用いた。降伏モーメント $M y$ 及U゙終局モーメ ント $\boldsymbol{M u}$ は, 断面内の応力の釣り合いから中立軸を求めて算定し た。せん断応力度〜歪み関係の第 1 折れ点は, コンクリートの斜めせ ん断ひび割れ点を $\tau c=\sqrt{(\sqrt{F c} \times(\sqrt{F c}+\sigma v))}$ により定義した点 $(\tau c$, $\gamma)$ とした。曲げに対する履歴特性は, 最大点指向型ディグレーディ ングトリリニアモデルとした。減衰定数は，1 次および 2 次に对して $2 \%$ となるレーリー減衰とした。設計用地震時応力は，4 波の最大応 答値を包絡するように定めた。図 7 にレベル 2 時の 4 波の地震時最 大応答值と風荷重時最大応答を示す。

概ね風荷重が支配的となっている。

\section{3 杭基磷設計}

図 8 には,ボーリングにより得られた土質柱状図を示す。ボーリン グポイントは 4 点で, 煙突各コーナ一部付近で実施した。建設地の地 層構成は $\mathrm{GL}-9 \mathrm{~m}$ までは埋め土が一様に分布している。 GL-9m 〜ー23m までは粘土，シルトを主体とした沖積粘土層が分布し含水 量が非常に多く軟弱層である。支持首となる硬質な砂岩を主体とす る $\mathrm{CL}, \mathrm{CM}, \mathrm{CH}$ 級岩盤が $\mathrm{GL}-17$ - $23 \mathrm{~m}$ 以深になだらかな傾斜で

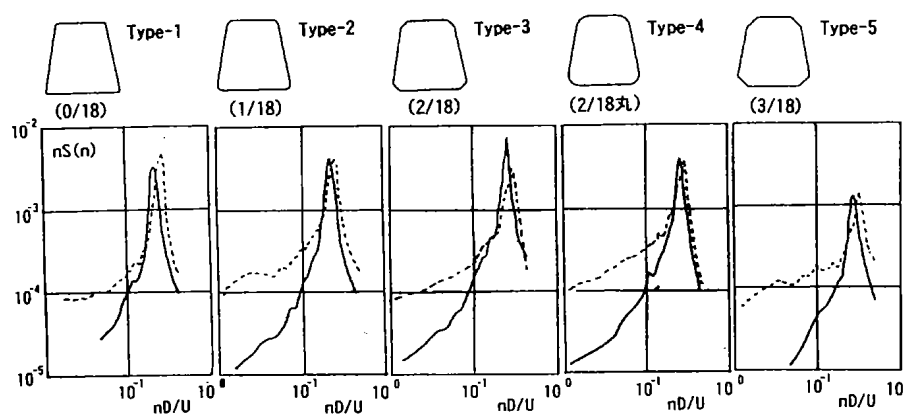

実線：風向角 180 度 $Y$ 方向振動 破線：風向角 90 度 $\mathrm{YX}$ 向振動

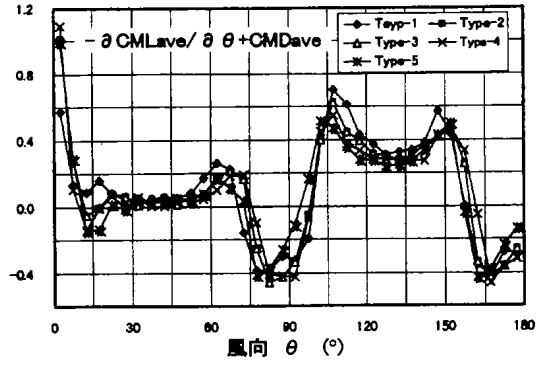

図 4 Den Hartog の判定值

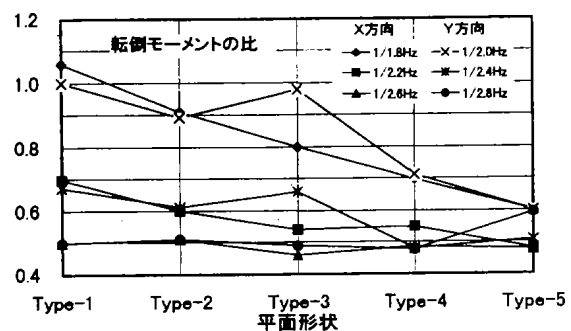

図 6 固有周期と転倒モーメメント

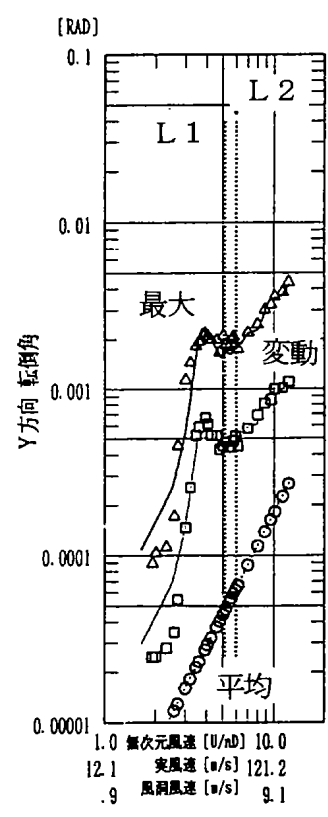

図 5 風速と応答関係
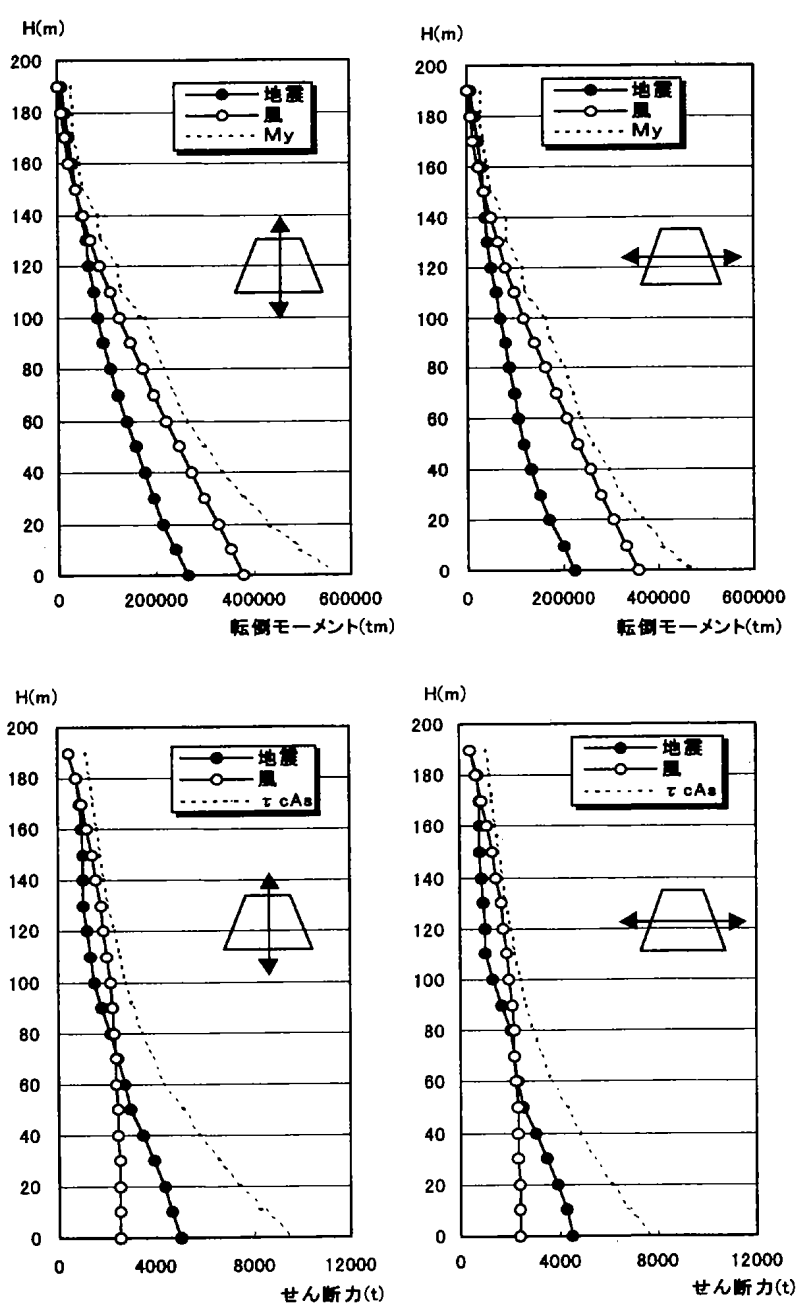

$M y ：$ 降伏モーメント

$\tau c ：$ U゙割れ時せん断応力度 $A s ：$ せん断断面積 
分布する。岩盤の一軸圧縮試験結果にばらつきはあるが，概ね CL， $\mathrm{CM}$ 級で $50 \sim 285 \mathrm{~kg} / \mathrm{cm}^{2}\left(5 \sim 28 \mathrm{~N} / \mathrm{mm}^{2}\right)$ である。杭先端は, $\mathrm{GL}-28 \mathrm{~m}$ として岩盤中に平均 $6.5 \mathrm{~m}$ 程貫入させた。

地上部の筒体 RC 壁の直下に地中連続壁杭を配置することにより 筒体壁と杭が構造的に連続性を保持し鉛直荷重, 水平荷重を支持地 盤に伝達させる。転倒モーメントに对しては，杭先端を岩盤中に梁 く貫入させて構造体自重と地盤反力及び地盤摩擦により浮き上がり に抵抗する。

杭の風荷重・地震荷重による水平力に対する設計に関して, 地中 連続壁杭を線材に置換した弾性支承梁解析の結果を示す。解析モデ ルは, 杭及び地盤ばねをモデル化し図 9 に示す。図中の地盤の物理特 性は敷地の地盤報告書によるものだが, 岩盤の変形係数は文献 2)に よる。岩盤の出現レベルは，地盤調査から GL $-17 \mathrm{~m} \sim-23 \mathrm{~m}$ に傾斜 して分布しているが，地盤抵抗の評価として安全側に GL-23m と した。杭先端には，鉛直方向の地盤剛性による回転ばねをモデル化 した。水平力による転倒モーメント，せん断力に対する抵抗機構と

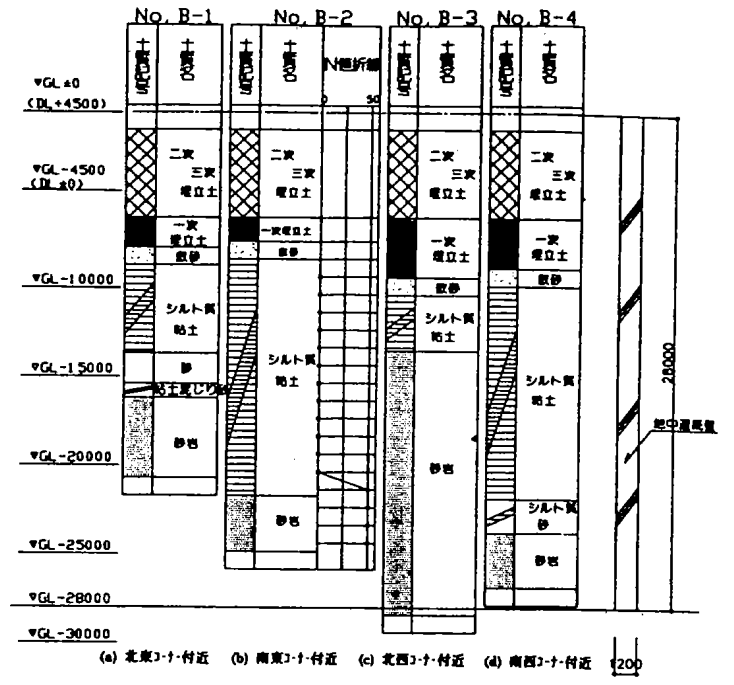

図 8 土質柱状困

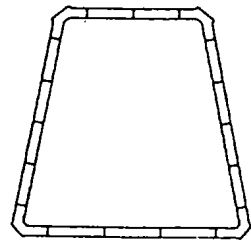

埋土居
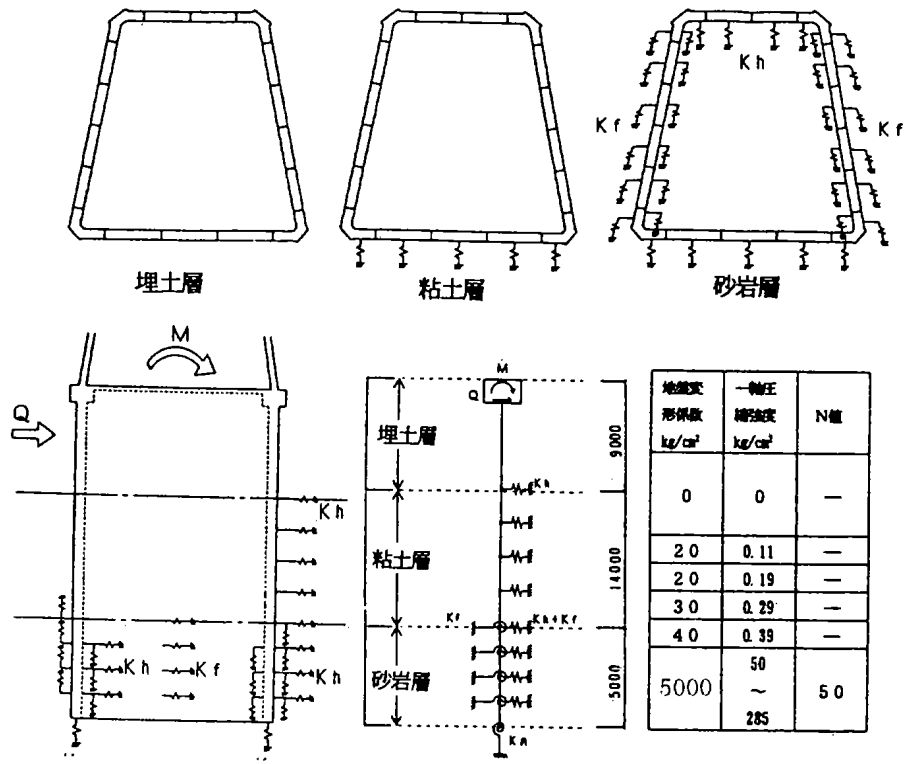

図 9

地盤ばねモデル概要
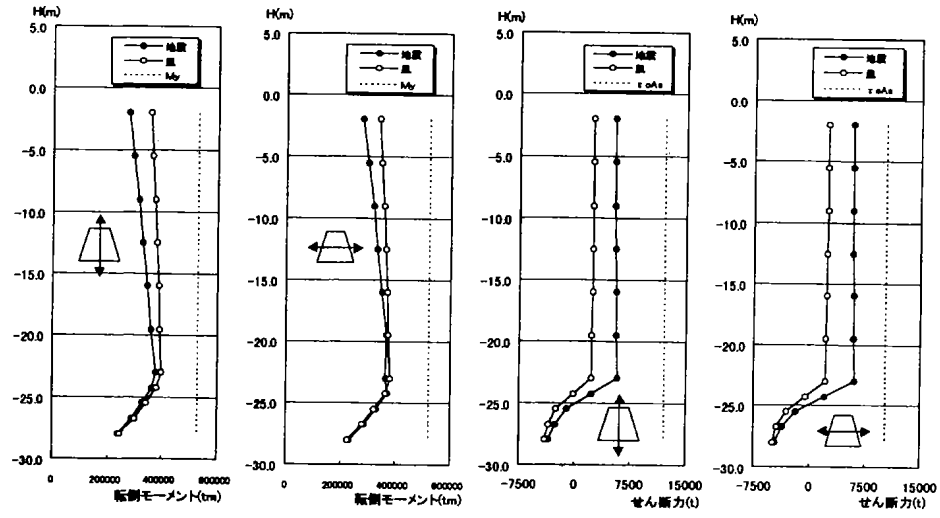

$M y$ ：降伏モーメント， $\tau c A s ：$ 斜めせん断ひび割れ強度

- 圧縮側 $\sigma v=N / A p-\sum M / Z-\{0.8(q u / 2) L c \Phi-W p\} / A p$

ここで, $\sigma v$ : 杭先端支持力度 $\left(\mathrm{t} / \mathrm{m}^{2}\right), N$ : 杭頭軸力 $\left(\mathrm{t} / \mathrm{m}^{2}\right), A p$ : 杭先端断面橨 $\left(\mathrm{m}^{2}\right), \Sigma M:$ 岩盤中の回転地盤ばねの和 $(\mathrm{tm}), Z$ : 杭先端断面係数 $\left(\mathrm{m}^{3}\right), W p$ : 杭水中自重 $(\mathrm{t}),(\mathrm{qu} / 2)$ : 杭周面最大 摩擦力度 $\left(20 \mathrm{t} / \mathrm{m}^{2}\right), L c \Phi$ : 岩盤中の杭周面摩摖面積 $\left(\mathrm{m}^{2}\right), n$ : 安全 率 1.5 (レベル 1)，1.2（レベル2）である。

\section{4. 煙突の施工概要}

\section{1 地中連繶壁工事}

地中連続壁工事は, 平成 9 年 2 月 1 日に着工し, 地盤改良工事, 地 中連続壁溝掘削工事，鉄筋・コンクリート工事等を行い，平成 9 年 7 月2 日に完了した。

施工場所の地盤は, 埋土層, シルト層, 砂岩層の 3 層から形成され ている。地盤最上部が埋戻し地盤のため，初めに，掘削時の壁面崩 壊を防止する目的で自硬性安定液による地盤改良工事を行った。

地盤改良工事完了後，地中連続壁溝掘削工事を行った。掘削は, 地盤の地質を考慮し能率良く掘削するために，油圧クラムシェル式 掘削機とリバースサーキュレーション方式の回転水平多軸式掘削機 を使用した。掘削中, 当初確認されていた硬質岩盤よりも更に硬い

図10 杭体の最大応力 
超硬質岩盤が大量に存在し，掘削能率が低下した。そこで，硬質砂 岩層を掘削するため新開発した特殊ティースをもつカッタードラム を有する回転水平多軸式掘削機を導入した。その結果, 掘削能率が 大幅に改善され、ほほ予定工期通りに工事を完了した。

掘削溝の精度 (傾斜) は, 油圧クラムシェル式掘削機では超音波 溝壁測定機を用いて掘削深度 $10 \mathrm{~m}$ 毎かつ必要に応じて, 回転水平多 軸式掘削機では，掘削機本体に内藏された掘削精度検出装置及び超 音波溝壁測定機を用いて管理した。その結果，地中連続壁杭の掘削 精度（傾斜）は, 平均 1/850（基準值：1/300 以上）とすることがで きた。

地中連続壁溝を掘削後, 鉄筋籠を掘削溝内に㨂入し, コンクリー トを打設し，地中連続壁杭が完成した。

\section{2 簡体スリップフォームエ章}

今回の煙突外筒工事は, (1)平面形状が台形で基部と頂部の形状が 大きく変化する上，各壁面コーナ一部の稜線にそれぞれ違う2 次曲 線を適用 (2) $\mathrm{GL}+60 \mathrm{~m}$ までの内壁面に 7 個所の RCリブを設置な ど非常に難易度の高い工事であった。この非常に複雑な形状を有す る RC 造超高焐突を安全に精度良くかつ効率的に施行するために， 特殊形状に対応できる高性能のスリップフォームシステムを採用し た。

筒体 SF 工事は，平成 9 年 7 月 23 日に着工し， $S F$ 装置組立，スラ イド, 盛替え, 解体を行い, 平成 10 年 9 月 11 日に完了した。この間, 悪天候による工事の中止日が6 日あったが，おおむね天候に恵まれ， 構造物を予定の工期に完了することができた。

図 11 にS 装置及びヨーク周辺詳細断面図を示す。このシステム は, SF 装置・計測制御装置・コンクリート荷揚機械・煙突クレーン・ 人荷エレベーター等から構成される。

図 12 に精度管理システム概略図を示す。当工事で使用した SF 装 置は, 壁厚・径・型枠勾配をそれぞれ筒体の形状変化に合わせて調 整する機構を備えている。これらの測定データに加え SF 装置の高 さ，中心偏位（ずれ）及び各ヨークのレベル計測データが SF 装置上 の中央制御室の精度管理システムコンピュータに送られる。これら のデー夕を処理し，ディスプレイ画面に表示して SF 装置の状態を リアルタイムに監視及びコントロールする。この精度管理システム によって，高品質の構造物を安全に施工することができる。

図 13 にヨーク割付け図を示す。スライド工事開始時は, ヨークを 51 台配置し, 旌体形状の変化に伴いコーナー部のヨークを順次解体 して，最終時には 23 台とした。

コンクリートの打設は, 約 GL $+30 \mathrm{~m}$ まではディストリビュータ を使用したポンプ圧送方式，それ以降はコンクリート搬送リフトと バッテリー台車の併用方式で行った。

壁直線部の縦筋配筋は，地上で組み立てた縦筋パネルをクレーン で吊り込んで配筋し，壁コーナー部の維筋配筋と横筋配筋は，在来
工法で配筋した。

本施工では，安全・品質・工期をよりレベルアップするために， 従来のSF 工事に加えて，以下の新技術を導入して工事を行った。

(1) 型枠には, 打設コンクリートが型枠に付着するのを防止し夜間 空スライド中止を目的として，鋼製型枠内面にテフロン系特殊 シートを貼り付けた付着防止型枠を開発した。

(2) 台形平面形状, コーナ一部曲面, 壁内面のコンクリートリブ等 の複雑な軀体形状に対応するために，8種類の型枠パネルを組み 合わせて施工した。

(3) 平面形状の大きな変化に対応可能な, 上下面フラットな上段 ビームを新開発・使用した。

(4) SF 工事中, 大量の資材の揚重と SF 装置解体の合理化のため, 1 ton $\times 12.5 \mathrm{~m}$ 大型クレーンを $\mathrm{SF}$ 装置上に設置した。

(5) SF 装置上において，コンクリートの運搬・打設に操作性が良く 静かなバッテリー台車を新開発・使用した。

（6）壁直線部縦筋配筋で採用した縦筋パネルの巾，鉄筋本数等を自 由に調整できる，縦筋パネルユニット化金物を開発した。

5.まとめ

電突の耐風設計では，渦励振の影郬を配虑し，台形平面の隅切り 部形状を 5 タイプのモデルを用いて行った風力実験に基づき合理的 に定めた。隅切り形状は, 台形の辺長に対して $2 / 18$ とした。レベル 2 時の設計応力は, 転倒モーメントについては概ね風荷重が支配的 である。

耐震設計では，地中連続壁杭を硬質な岩盤に貫入し，風・地震時 の水平力に抵抗させ，地上部と地下部の構造的な連続性を高めた。 地中連続壁工事は，埋め立て地の軟弱地盤における掘削のため， 掘削溝の崩壊や傾斜が懸念されたが，泥水固化式地盤改良工法と地 中連続壁工法を組み合わせることによって，所定の品質の地中連続 壁杭を施工することができた。

娷突筒体工事は, 非常に難易度の高い工事であったが, 各種の新 技術を採用して施工に当たった結果, 構造物を予定の工期に完成す ることができた。

なお，本煙突の設計，施工にあたり，ご尽力いただいた称大林組 の方々に感謝いたします。

\section{参考文献}

1) Den Hartog 著, 谷口 修, 藤井澄二 共訳：機械振動論 (改訂 版)；コロナ社

2）岩盤分類とその適用；土木工学社

3）連続地中壁基礎設計施工指針・同解説：社日本道路協会 


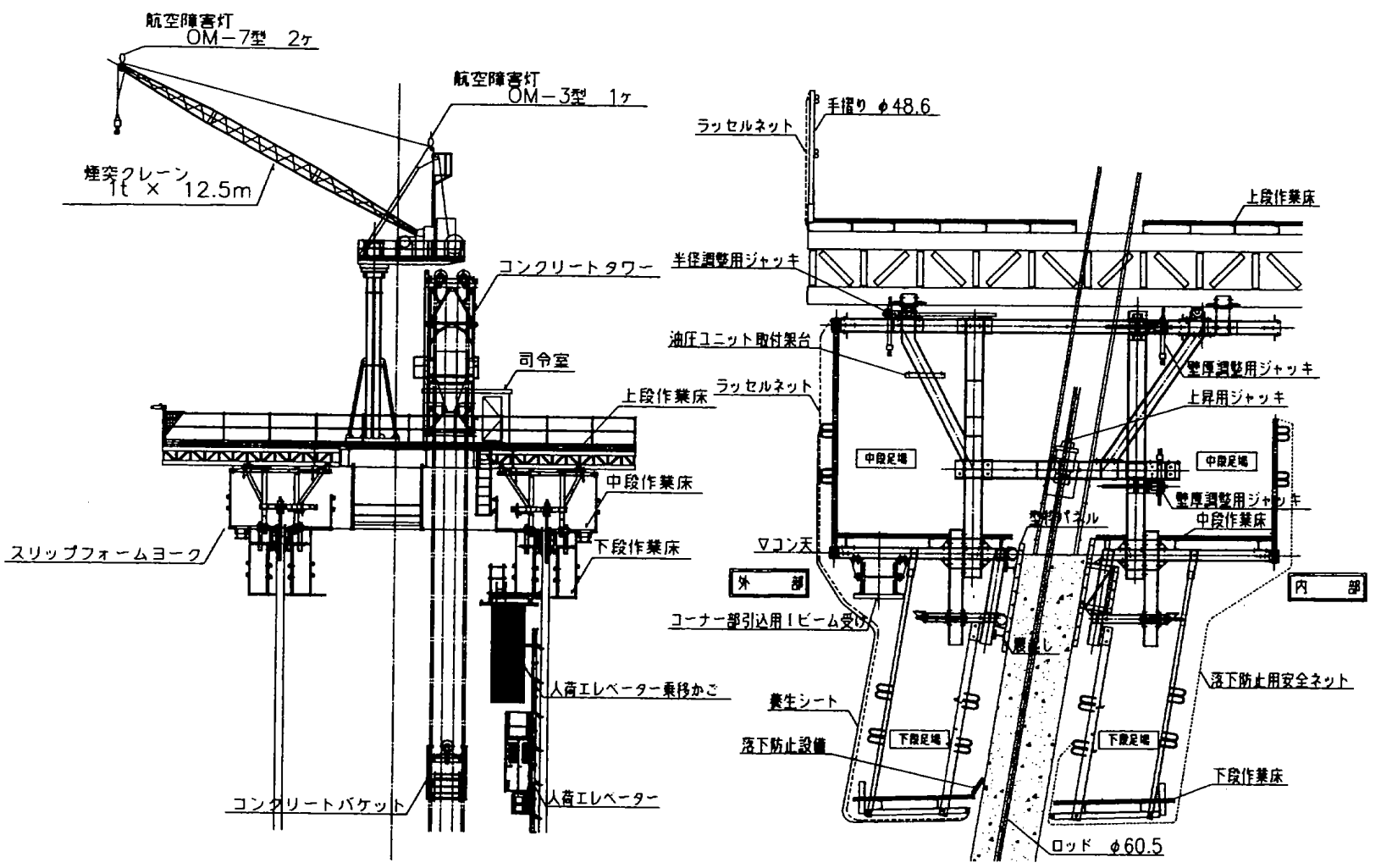

(a) 全体図

(b) $\exists$ ヨ周辺図

図11 SF 装置＼cjkstart詳細断面図

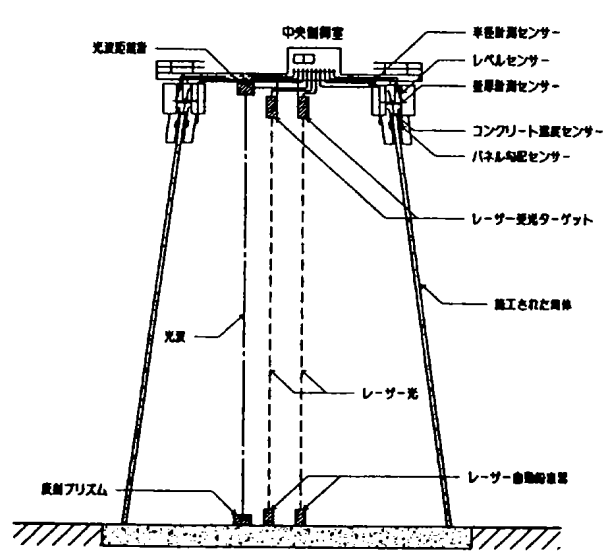

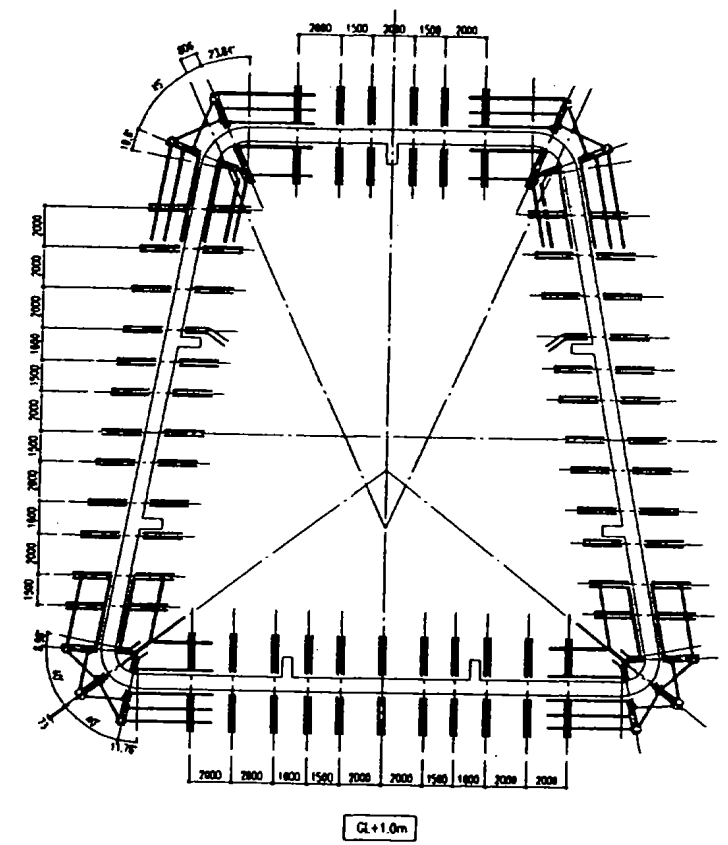

(a) 施工開始時

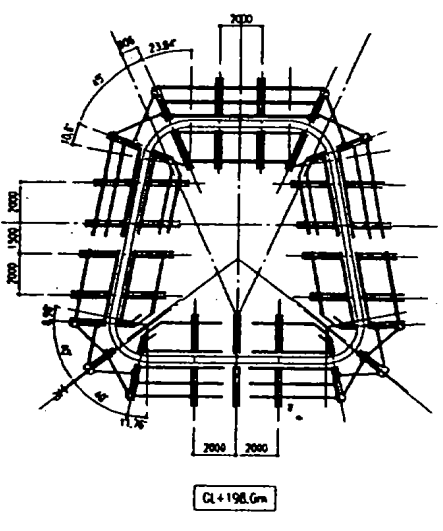

(b) 施工最終時

図12 精度管理システム概略図

図13 ヨーク割り付け困 